\title{
Pengaturan Pemutusan Hubungan Kerja dalam Perspektif Kepentingan Ekonomi dan Hak Asasi Manusia
}

\author{
Budi Santoso
}

DATA NASKAH

Masuk: 27 Agustus 2017

Diterima: 9 Oktober 2017

Terbit: 1 Desember 2017

KORESPONDEN PENULIS:

Fakultas Hukum Universitas Brawijaya, JI. MT. Haryono No. 169, Malang 65145

budi.santoso@ub.ac.id

\begin{abstract}
I ssue of dismissal is closely related to employer economics interests and human rights. The regulation must be consider in both aspects. Therefore, this article aims to analyze the comparation between economics perspective and human rights perspective on the issue. This article issued comparative approach. Then, it is concluded that on the economics perspective although the N eoclassical E conomics Theory and the Theory of $\mathrm{N}$ ew Institutional E conomics have a different perspective, whether or not it stipulated by legislation, but both have a common view that the dismissal should not affect the company's productivity and efficiency. M eanwhile, on the human rights perspective, the workers are entitled to a fair dismissal, both substantive and procedural.
\end{abstract}

K ey words: dismissal, human rights, economics

\section{ABSTRAK}

Masalah pemutusan hubungan kerja berkaitan erat dengan kepentingan ekonomi pengusaha dan hak asasi manusia. Pengaturannya harus memperhatikan kedua kepentingan tersebut. O leh karena itu, tulisan ini bertujuan untuk menganalisis perbandingan antara pandangan kepentingan ekonomi dan hak asasi manusia terhadap aspek pengaturan pemutusan hubungan kerja. Melalui penggunaan pendekatan perbandingan, diperoleh hasil bahwa dalam perspektif kepentingan ekonomi, walaupun terdapat pandangan yang berbeda antara penganut Teori Ekonomi Neoklasik dengan Teori Ekonomi Kelembagaan Baru mengenai perlu tidaknya masalah pemutusan hubungan kerja diatur dalam peraturan perundang-undangan, namun keduanya mempunyai persamaan pandangan bahwa hal pemutusan hubungan kerja seharusnya tidak berdampak pada produktivitas dan efisiensi perusahaan. Sementara, 
dalam perspektif hak asasi manusia, pekerja mempunyai hak untuk tidak diputus hubungan kerjanya secara tidak adil. Pekerja berhak untuk memperoleh perlakuan yang adil atas maksud pemutusan hubungan kerja oleh pengusaha. Pengaturannya harus mencerminkan keadilan, baik keadilan substantif maupun prosedural.

Kata kunci: pemutusan hubungan kerja, hak asasi manusia, ekonomi

\section{PENDAHULUAN}

Hubungan kerja merupakan suatu hubungan hukum yang bertimbal balik antara pemberi kerja dan pekerja yang mempunyai unsur pekerjaan, upah, dan perintah. Idealnya, suatu hubungan kerja berlangsung hingga jangka waktu yang diperjanjikan, baik jangka waktu tertentu atau tidak tertentu. Namun dalam kenyataannya, seringkali suatu hubungan kerja berakhir sebelum waktunya atas sebab-sebab tertentu. Krisis ekonomi yang berdampak pada penurunan produksi dan penjualan dapat menyebabkan pengurangan pekerja secara massal oleh pengusaha atau mungkin seorang pekerja sudah tidak dapat bekerja lagi karena sakit berkepanjangan atau pekerja melanggar tata tertib perusahaan. Terkadang juga pekerja mengundurkan diri dari pekerjaannya atau pekerja beralih pekerjaan ke pekerjaan yang lebih baik di perusahaan lain. Hal-hal tersebut dapat menyebabkan terjadinya pemutusan hubungan kerja (selanjutnya disebut PHK).

Ditinjau dari sumbernya, secara umum PHK dapat ditimbulkan dari empat sumber yang berbeda, yaitu: pertama, PHK oleh pemberi kerja, misalnya PHK karena pelanggaran tata tertib kerja dan PHK karena penutupan perusahaan; kedua, PHK oleh pekerja, misalnya pekerja mengundurkan diri (resign); ketiga, PHK oleh bersama pemberi kerja dan pekerja pada waktu yang telah ditetapkan, misalnya pada waktu selesainya pekerjaan seperti yang telah diperjanjikan; dan keempat, PHK oleh keadaan tertentu, misalnya kematian pekerja (Rao, 2007: 80-81). Dalam konteksPHK oleh pemberi kerja tidak jarang menimbulkan perselisihan akibat adanya perbedaan kepentingan yang tajam, misalnya pemberi kerja memutuskan hubungan kerja atas alasan pekerja tidak disiplin masuk kerja, di pihak lain, pekerja masih ingin melanjutkan hubungan kerja tersebut dan mengemukakan bahwa ketidakhadiran kerjanya tersebut karena alasan sakit.

Persoalan PHK oleh pemberi kerja adalah salah satu isu penting dalam praktik perburuhan dari waktu ke waktu, terutamanya jika dikaitkan dengan eksistensi hak asasi manusia dan kepentingan ekonomi dalam suatu hubungan kerja antara pemberi kerja dan pekerja (Allen, et.al., 2007: 1). Isu ini biasanya perihal perdebatan tentang perlu tidaknya pembatasan oleh negara atas kewenangan pemberi kerja dalam melakukan PHK. Pihak yang satu menekankan pentingnya perlindungan kepada pekerja atas PHK yang dilakukan atas sebab-sebab yang melanggar hak asasi dan prinsip-prinsip masyarakat bebas (Collins, 1991: 232). Pekerja harus dilindungi dari praktik pasar kerja yang kapitalis. Sebaliknya, pihak lainnya menilai ketatnya persaingan bisnis akibat globalisasi ekonomi yang tidak mengenal batas kedaulatan negara memerlukan adanya pasar tenaga kerja yang lebih fleksibel. Negara seharusnya memainkan peran yang minimal dalam konteks labour market (Betten, 1995: 1). Dalam praktik PHK atas alasan perusahaan mengalami kelebihan jumlah pekerja akibat adanya jumlah permintaan produksi yang terus-menerus, misalnya, tidakjarang pengusaha melakukan hal tersebut dengan tidak menyampaikan bukti-bukti yang mendukung alasan yang dikemukakan. Pengusaha menilai bahwa hal mengenai PHK ini adalah hak prerogatifnya.

\section{RUMUSAN MASALAH}

Berdasarkan uraian di atas, tulisan ini hendak menganalisis bagaimana sebenarnya perbandingan antara pandangan hak asasi manusia dengan kepentingan ekonomi perusahaan atas persoalan PHK. Tinjauan terhadap pandangan hak asasi manusia atas PHK akan dikaji dari pendapat-pendapat para ahli, Deklarasi Universal PBB mengenai hak asasi manusia, Konstitusi ILO, dan instrumen internasional lainnya tentang hak asasi manusia. Di pihak lain, tinjauan terhadap pandangan ekonomi atas PHK akan dikaji dari pandangan dua teori ekonomi pada abad ke-20 yang paling berpengaruh dalam bidang labor economics, yaitu Teori Ekonomi Neoklasik dan Teori Ekonomi Kelembagaan Baru (Kaufman, "Economic Analysis of Labor Markets and Labor Law: An Institutional/ Industrial Relations Perspective", http:// www.employmentpolicy.org/topic/578/research/ economic- 
analysis-labor-markets-and-labor-law-institutionalindustrialrelations-p, diunduh pada Senin, 26 Oktober 2015, jam 22.17 WIB).

\section{HASIL PENELITIAN DAN ANALISIS}

\section{A. PHK dalam Perspektif H ak Asasi Manusia}

1. Pekerja bukan Komoditas

Gagasan moderen tentang hak asasi manusia menyatakan bahwa semua manusia harus diberikan hak-hak dasar tertentu berdasarkan martabat kemanusiaan. Hak asasi ini bersifat universal dan imperatif dengan menitikberatkan pada suatu moral khusus yang mengabaikan pertimbangan-pertimbangan lainnya (Collins, "Theories of Rights as) ustifications for Labour Law", http://www.Ise.ac.uk/collections/law/ staff\%20 publications \%20full\%20text/ collins/ch9.pdf, diunduh pada Sabtu, 14 November 2015, jam 21.35 WIB). Menurut Onaga, gagasan ini dapat diperoleh tidak hanya dari sumber-sumber agama tapi juga bisa muncul dari keyakinan sekuler. Ketika orang meyakini bahwa semua orang memiliki martabat sebagai manusia, maka tidak terlalu sulit untuk meyakini bahwa setiap orang harus menikmati hak tertentu yang esensial untuk menjaga martabat tersebut. Pemikiran atas hak-hak tersebut biasanya mencakup hak untuk bebas dari siksaan, bebas dari kerja paksa, bebas dari eksploitasi, kebebasan berpikir dan mengeluarkan pendapat, kebebasan berekspresi, hak ekonomi dan sosial seperti hak atas makanan, perumahan, kesehatan dan pekerjaan (Steni, 2008: 6). Hak atas pekerjaan menyiratkan di dalamnya termasuk pula hak untuk memperoleh perlakuan yang adil dalam pekerjaan.

Selanjutnya, Pasal 23 dan 24 Deklarasi Universal Hak Asasi M anusia (1948) dengan jelas telah memberi tempat kepada hak atas pekerjaan dan hak dalam pekerjaan sebagai bagian dari hak asasi manusia:

\section{Pasal 23}

1. Setiap orang berhak atas pekerjaan, berhak dengan bebas memilih pekerjaan, berhak atas syarat-syarat pekerjaan yang adil serta baik, dan berhak atas perlindungan dari pengangguran.

2. Setiap orang, tanpa diskriminasi, berhak atas pengupahan yang sama untuk pekerjaan yang sama.

3. Setiap orang yang melakukan pekerjaan berhak atas pengupahan yang adil dan baik yang menjamin kehidupannya dan keluarganya, suatu kehidupan yang pantas untuk manusia yang bermartabat, dan jika perlu ditambah dengan perlindungan sosial lainnya.

4. Setiap orang berhak mendirikan dan memasuki serikatserikat pekerja untuk melindungi kepentingannya.

\section{Pasal 24}

Setiap orang berhak atas istirahat dan liburan, termasuk pembatasan-pembatasan jam kerja yang layak dan hari libur berkala, dengan menerima upah.

Tegasnya, hak untuk bekerja dan hak dalam bekerja sebagaimana yang dinyatakan dalam kedua pasal di atas termasuk hak asasi manusia yang fundamental (Drzewicki, 2001: 223). Hak asasi manusia dalam bidang pekerjaan ini berkaitan dengan peran dan jati diri sebagai seorang pekerja (Mantouvalou, "Are Labour Rights Human Rights?", http:// www.ucl.ac.uk/laws//ri/papers/VM antouvalou_Are_labour_rights_human_rights.pdf, diunduh pada Rabu, 4 November 2015, jam 23.20 WIB). Pekerja sebagai manusia berhak untuk diperlakukan dengan adil dan layak dalam hubungan kerja, termasuk hak diperlakukan secara adil dalam hal terjadinya PHK. Pekerja berhak untuk memperoleh perlindungan terhadap PHK yang sewenang-wenang (Hepple, 1981: 66). Hak untuk tidak diputuskan hubungan kerjanya secara tidak adil ini juga sejalan dengan konsepsi jaminan pekerjaan yang sangat dipengaruhi oleh gagasan hak asasi manusia, yaitu menghormati dan memperlakukan pekerja sesuai dengan harkat dan martabatnya sebagai manusia.

Menurut Collins, terdapat dua prinsip penting yang mendasari hak pekerja untuk tidak diputuskan hubungan kerjanya secara tidak adil, yaitu dignity principle dan autonomy principle (Davies, 2004: 162). Dignity principle mengemukakan penghormatan dan pengakuan atas harga diri pekerja, yaitu dengan mensyaratkan maksud pemberi kerja dalam memutuskan hubungan kerja harus mempunyai alasan yang rasional. PHK yang tidak mempunyai dasar yang rasional akan melanggar harga diri pekerja, misalnya PHK atas alasan kehamilan, alasan status perkawinan, atau alasan pekerja telah berusaha untuk meminta haknya atas upah minimum. Sementara itu, autonomy principle mengakui 


\section{MEDIA HUKUM}

hakikat kerja sebagai salah satu cara yang penting bagi pekerja untuk memberi arti dalam kehidupannya. Pemberi kerja tidak seharusnya campur tangan terhadap apa yang pekerja lakukan di luar waktu kerjanya. Prinsip autonomy menunjukkan rasa hormat kepada pekerja sebagai individu bebas yang menginginkan dirinya mampu menata kehidupannya.

Pernyataan-pernyataan di atas telah menegaskan bahwa hak untuk tidak diputuskan hubungan kerjanya secara tidak adil (just cause principle) merupakan prinsip dasar hak asasi manusia dalam aspek PHK. Ukuran keadilannya adalah keadilan substansi dan keadilan prosedural. Keadilan substansi menunjuk kepada alasan-alasan yang rasional, sedangkan keadilan prosedural menunjuk kepada pemberian kesempatan kepada pekerja untuk membela dirinya bahwa PHK oleh pemberi kerja adalah tidak beralasan (Dau-Schmidt, 2009: 69).

Just cause principle sebagai suatu prinsip dalam menjamin pekerjaan sebenarnya telah timbul sebagai akibat dari pengaruh negatif Revolusi Industri yang menyebabkan banyak negara menyadari bahwa prinsip kebebasan berkontrak, yang merupakan salah satu prinsip dari teori umum liberalisme ekonomi, mempunyai batasnya. Batas ini terutama disebabkan oleh bargaining position pekerja yang lemah dibanding pemberi kerja (Hepple, 1986: 6). Kelemahan ini biasanya mulai muncul pada saat pembuatan perjanjian kerja. Walaupun dalam pembuatan perjanjian kerja terkandung asaskeseimbangan para pihak, namun konsep perjanjian kerja berbeda dengan konsep perjanjian pada umumnya yang bercirikan adanya keseimbangan para pihak. Kedudukan pekerja selalu berada pada pihak yang lemah (Santoso dan Ratih, 2012: 206). Oleh karena itu, pekerja perlu dilindungi dengan peraturan hukum terhadap potensi penyalahgunaan bargaining position pemberi kerja yang kuat, termasuk melindungi pekerja terhadap PHK sewenang-wenang.

Organisasi Perpekerjaan Internasional (ILO) sendiri juga telah mengakui just cause principle sebagai prinsip dasar hak asasi manusia dalam aspek PHK. Hal ini seperti tersirat dalam slogan 'labour is not a commodity' (pekerja bukan komoditas) yang termaktub dalam Pasal 1 Konstitusi ILO (http://www.ilo.org/ilolex/english/iloconst.htm, diunduh pada Senin, 7 Desember 2015, jam 20.45 WIB). Slogan ini muncul sebagai lawan terhadap konsep 'labour is a com- modity' yang merupakan bagian dari 'labour theory of value' sebagaimana yang dicetuskan oleh Adam Smith, dan telah diakui dalam teori ekonomi liberal abad ke-19 (Evju, "Labour is not a Commodity: A Reappraisal", http://www. labourlaw research. net/Portals/0/06\%20Labour\%20-\%20Commodity\%20Reppraisal.pdf, diunduh pada Rabu, 18 November 2015, jam 22.10 WIB). Teori ini berpegang pada konsep bahwa nilai suatu komoditas ditentukan oleh penggunaan pekerja dalam produksi (Investovedia, "Definition of Labor Theory Of Value", http://www.investopedia.com/ terms/l/ labor-theory-of-value.asp \#axzz2DNs1SjMA, diunduh pada Rabu, 7 Oktober 2015, jam 22.15 WIB).

Slogan 'labour is not a commodity' memperlihatkan ciriciri tersendiri berkaitan dengan pekerjaan yang menyebabkan pekerja tidak seperti komoditas lazimnya dalam praktik bisnis. Pekerja adalah manusia, bukan komoditas atau barang. Dengan menyetujui bekerja untuk orang lain, tidak berarti bahwa pekerja setuju untuk diperlakukan seperti barang yang dapat digunakan dan dipindahtangankan sekehendak hati pemiliknya. Pekerja mengharapkan diperlakukan secara adil dalam hubungan kerja, baik yang berhubungan dengan upah dan kesejahteraan, kesehatan, keselamatan, keberlangsungan pekerjaan, dan sebagainya.

\section{Isu PHK dalam Instrumen Hak Asasi Manusia Internasional}

Sejak Konstitusi ILO mengakui bahwa dalam bidang perburuhan juga terdapat dimensi hak asasi manusia, yakni pekerja adalah manusia yang berhak diperlakukan sesuai harkat dan martabatnya, maka telah lahir beberapa instrumen internasional bidang hak asasi manusia yang memberi perhatian terhadap isu PHK. Instrumen tersebut antara lain European Social Charter, Charter of Fundamental Rights of the European Union, Konvensi ILO No. 158, dan Convention on the Elimination of All Forms of Discrimination Against Woman.

Pasal 4 ayat (4) European Social Charter 1961 (http:// polis. osce.org/library/f/2667/ 466/CoE-ITA-RPT-2667-EN-46, diunduh pada Rabu, 18 November 2015, jam 20.30 WIB) mengandung kewajiban bagi pemberi kerja untuk memastikan bahwa pekerja menerima jangka waktu pemberitahuan (notice) yang patut jika hubungan kerja 
mereka akan diputuskan. Hak menerima pemberitahun ini merupakan hak untuk diberi peringatan terlebih dahulu bahwa pekerja akan diputuskan hubungan kerjanya. Hak ini penting bagi pekerja supaya mempunyai cukup waktu untuk mencari dan memperoleh pekerjaan baru.

Selanjutnya, perhatian lebih telah diberikan oleh Pasal 24 the European Social Charter 1996 (http://www.coe.int/ t/dGHI/monitoring/Socialcharter/Presentation/ESCR Booklet/ English.pdf, diunduh pada M inggu, 15 November 2015, jam 21.50 WIB) yang merevisi the European Social Charter 1961 dengan mengharapkan peran negara untuk melindungi hak pekerja untuk tidak diputuskan hubungan kerjanya secara sewenang-wenang dan untuk memastikan bahwa pekerja yang diputuskan hubungan kerjanya akan mendapatkan kompensasi. Juga dalam Pasal 30 Charter of Fundamental Rights of the European Union (http://eur-lex.europa.eu/ LexUriServ/LexU riServ.do? uri = 0 : C:20 10:083: 0389:0403:EN:PDF, diunduh pada Rabu, 18 November 2015, jam 22.40 WIB) menyatakan bahwa "Setiap pekerja mempunyai hak untuk perlindungan terhadap PHK yang tidak adil".

Instrumen internasional bidang hak asasi manusia yang lebih luas terkait dengan hak pekerja atas PHK yang adil adalah Konvensi ILO No. 158 Tahun 1982 tentang Pemutusan Hubungan Kerja atas Inisiatif Pemberi Kerja (http://www.ilo.org/wcmsp5/groups/public/-asia/-ro-bangkok/-ilo-jakarta/ documents/legaldocument/wcms_149912.pdf, diunduh pada Rabu, 18 November 2015, jam 23.05 WIB). Menurut Konvensi ini, hak pekerja yang paling asasi berkaitan dengan aspek PHK adalah hak untuk memperoleh jangka waktu pemberitahuan PHK. Pasal 11 Konvensi menghendaki peranan negara untuk mengakui hak pekerja memperoleh jangka waktu pemberitahuan PHK yang patut sebelum hubungan kerjanya diputuskan.

Walaupun demikian, hak pekerja untuk memperoleh jangka waktu pemberitahuan PHK tidak melindungi pekerja terhadap praktik PHK yang sewenang-wenang oleh pemberi kerja. Oleh karena itu, hukum harus mengawal adanya alasan yang sah dan adil oleh pemberi kerja untuk melakukan PHK. Dalam Konvensi ILO No. 158 ini telah dinyatakan beberapa alasan yang sah yang dapat digunakan oleh pemberi kerja untuk melakukan PHK, yaitu alasan ketidakmampuan bekerja, alasan ketidakdisiplinan, dan alasan ekonomi. Dua alasan pertama berkaitan dengan kondisi pekerja yang diputus hubungan kerjanya.

Pasal 6 Konvensi ILO No. 158 menyatakan bahwa ketidakhadiran sementara dari bekerja atas alasan sakit atau kecelakaan tidaklah menjadi alasan yang sah untuk dapat dilakukan PHK. Ini bermakna bahwa pemberi kerja hanya dapat melakukan PHK atas alasan ketidakmampuan bekerja yang berlangsung atau mungkin berlangsung lama. Alasan ketidakdisiplinan terjadi jika pekerja telah melanggar peraturan pemberi kerja. Pasal 7 menyatakan bahwa pekerja yang diputus hubungan kerjanya atas alasan ketidakmampuan bekerja atau ketidakdisiplinan perlu diberikan kesempatan untuk membela dirinya. Hal tersebut berkaitan dengan hak asasi untuk memperoleh prosedur penyelesaian yang adil.

Alasan ketiga, yakni alasan ekonomi, berkaitan dengan alasan kepentingan operasional perusahaan atau organisasi. Hal Ini meliputi kasus-kasus ketika perusahaan mengalami kemunduran dalam bisnisnya, misalnya turunnya produksi akibat terus menurunnya permintaan, sehingga mengakibatkan terjadinya kondisi tidak terdapatnya pekerjaan yang harus dikerjakan oleh sebagian pekerjanya. Kondisi ini menyebabkan pemberi kerja terpaksa mengurangi sebagian pekerjanya tersebut melalui program PHK massal atas alasan ekonomi walaupun tidak terdapat hal-hal yang salah dengan kerja pekerja.

Satu lagi substansi Konvensi ILO No. 158 yang memperjelas pengakuan eksistensi hak asasi manusia dalam bidang PHK adalah dinyatakannya keadaan-keadaan tertentu berkaitan hak asasi manusia yang dilarang digunakan sebagai alasan PHK oleh pemberi kerja. Hal ini sebagaimana yang dinyatakan dalam Pasal 5 Konvensi, yaitu:

1. Keanggotaan serikat pekerja atau keikutsertaan dalam kegiatan-kegiatan serikat pekerja diluar jam kerja atau, dengan persetujuan pengusaha, di dalam jam kerja;

2. memegang jabatan sebagai, atau bertindak atau telah bertindak dalam kapasitas sebagai, perwakilan pekerja;

3. pengajuan keluhan atau keikutsertaan dalam pengajuan gugatan terhadap pengusaha yang menyangkut dugaan pelanggaran hukum atau memanfaatkan otoritas administratif yang berwenang;

4. ras, warna kulit, gender, status perkawinan, tanggung 
jawab keluarga, kehamilan, agama, pendapat politik, kebangsaan atau status sosial; atau

5. ketidakhadiran kerja selama cuti hamil dan melahirkan.

Beberapa keadaan yang dilarang sebagai alasan PHK nampakjuga dalam instrumen hak asasi manusia internasional lainnya. M isalnya, dalam Pasal 11 ayat (2)(a) Convention on the Elimination of All Forms of Discrimination Against Woman (http://www.un.org/ womenwatch/daw/ cedaw/text/econvention.htm, diunduh pada Jumat, 20 November 2015, jam 21.35 WIB) dinyatakan adanya larangan melakukan PHK atas alasan pekerja hamil, alasan pekerja mengambil cuti melahirkan, atau alasan yang bersifat diskriminasi dan gender. Instrumen ini menekankan pentingnya perlindungan pekerja atas praktik PHK untuk memastikan hak-hak lainnya ditegakkan, misalnya hak atas alasan PHK yang adil dan hak atas kompensasi PHK.

\section{B. PHK dalam Perspektif Kepentingan Ekonomi}

Untuk menganalisis bagaimana perihal PHK dalam perspektif kepentingan ekonomi, maka dapat dikemukakan setidaknya dua teori besar dalam bidang ekonomi, yaitu Teori Ekonomi Neoklasik (the Neoclassical Economics Theory) dan Teori Ekonomi Kelembagaan Baru (the Theory of New Institutional Economics).

\section{Teori Ekonomi Neoklasik: Menentang}

Pengaturan PHK

Sejak awal tahun 1980-an, sekelompok pakar ekonomi dan hukum yang berpengaruh, diantaranya Richard Epstein, Daniel Fischel, Edmund Kitch, William Landes, dan Richard Posner, telah membuat pandangan yang meyakinkan tentang deregulasi pasar kerja. Kelompok berpengaruh ini mendapat inspirasi dari para pakar ekonomi neoklasik yang telah populer sebelumnya, terutama kelompok pakar versi Chicago School di Amerika Serikat, yaitu Becker, Friedman, dan Stigler. Pandangan kelompok ini muncul sebagai respon terhadap Teori Ekonomi Kelembagaan yang berpendapat bahwa negara akan mendapat manfaat produktivitas dan efisiensi dari pengaturan hubungan kerja, termasuk pengaturan PHK (Dau-Schmidt et.al., 2009: 4).

Para penganut Teori Ekonomi Neoklasik menyatakan bahwa bentuk organisasi ekonomi yang paling efisien adalah ekonomi pasar bebas dimana semua barang dan jasa atau pekerjaan diperdagangkan dalam pasar persaingan yang sempurna. Kegiatan permintaan dan penawaran dalam pasar yang kompetitif secara otomatis dan tanpa intervensi akan menggerakkan ekonomi ke batas kemungkinan tertinggi produksi (Miceli, 2004: 30).

Kegiatan permintaan dan penawaran serta harga yang fleksibel dalam ekonomi pasar bebas yang kompetitif secara otomatis akan menggerakkan ekonomi ke arah titik penggunaan sumber daya secara maksimal, termasuk sumber daya manusia. Oleh karena itu, pasar kerja yang berdaya saing dapat mengantarkan kepada dua keadaan yang sangat diinginkan, yaitu peraturan yang efisien dan penggunaan pekerja sepenuhnya secara maksimal. Pasar yang kompetitif menyebabkan peralihan sumber daya manusia yang sangat fleksibel dan adaptif sebagai respon terhadap situasi ekonomi yang berubah-ubah, dan pasar yang kompetitif meminimalkan biaya dan memaksimalkan produktivitas pekerja. Menurut para penganut Teori Ekonomi Neoklasik pula, justru putusan pengadilan dan peraturan perundangundangan yang meninggalkan doktrin 'at-will termination' seharusnya dicegah karena hal tersebut mempunyai dampak ekonomi yang buruk (Krueger, 1991: 644).

Diabaikannya doktrin 'at-will termination' menyebabkan ekonomi tidak kompetitif dan tidak efisien (Posner, 1984: 997). Peraturan hukum yang mengatur kewenangan pemberi kerja (pemilik modal), termasuk pembatasan kewenangan pemberi kerja dalam melakukan PHK, justru akan menghambat minimalisasi biaya dan maksimalisasi produktivitas pekerja (Dau-Schmidt, 2009: 7). Oleh karena itu, pemberi kerja seharusnya mempunyai kewenangan dan kebebasan mutlak untuk memutus hubungan kerja kepada pekerjanya, sama seperti pemberi kerja bebas memilih dan mempekerjakan pekerja (Epstein, 1984: 947).

Doktrin 'at-will termination' menjelaskan bahwa baik pemberi kerja maupun pekerja dapat memutuskan hubungan kerjanya pada saat kapanpun dan atas sebab apapun juga, sebab yang baik atau sebab yang buruk, atau bahkan tanpa sebab. Pekerja tidak mempunyai landasan peraturan untuk menentang PHK tersebut di pengadilan. Apa yang menjadi dasarnya adalah bahwa pemberi kerja tidak harus memberi justifikasi apapun untuk keputusan suatu PHK. Doktrin ini 
memberi kewenangan yang tidak terbatas bagi pemberi kerja maupun pekerja untuk memutuskan hubungan kerja (DauSchmidt, 2009: 68). Epstein menegaskan, justru doktrin 'atwill termination' sesungguhnya mempunyai tiga kelebihan bagi pemberi kerja, yaitu: dapat memotivasi pekerja, fleksibel, dan efisien untuk pengelolaan perusahaan. Berdasarkan kelebihan ini pula maka Epstein berpendapat bahwa doktrin ini perlu dipertahankan (Epstein, 1984: 966).

Walaupun demikian, menurut Davies, doktrin 'at-will termination' dianggap hanya akan memberi manfaat kepada pemberi kerja, sebaliknya tidak memberi manfaat kepada pekerja sekalipun. Pekerja tidak kebal terhadap PHK pada waktu kapanpun dan atas sebab apapun, sebab baik atau sebab buruk (Davies, 2004: 156). Tetapi pandangan ini dibantah oleh Epstein. M enurutnya, justru pekerja akan mempunyai jaminan pekerjaan berdasarkan doktrin 'at-will termination' karena kekuatan pasar mencegah pemberi kerja untuk bertindak secara sewenang-wenang. Pemberi kerja yang rasional tidak akan memecat pekerjanya yang produktif. Pemberi kerja akan menghadapi dua kerugian utama jika memecat pekerja yang produktif atas sebab-sebab yang tidak adil atau buruk, yaitu: pertama, kehilangan manfaat keahlian dan keterampilan pekerja itu dan terpaksa akan menanggung biaya untuk menggaji dan melatih penggantinya; kedua, citra atau nama baik pemberi kerja akan buruk (Epstein, 1984: 968). Jika citra perusahaan buruk di mata masyarakat maka hal ini bisa mempengaruhi penjualan hasil produksinya. Pula, perusahaan akan kesulitan mendapat tenaga kerja yang potensial akibat kekurang percayaan calon pelamar kerja kepada perusahaan tersebut.

\section{Teori Ekonomi Kelembagaan Baru: Mendukung} Pengaturan PHK

Teori Ekonomi Kelembagaan Baru lahir sebagai ‘perlawanan' terhadap tekanan neo-liberalisme, globalisasi ekonomi dan kekuatan-kekuatan lain yang bermaksud untuk melonggarkan rezim intervensi negara dalam usaha untuk meningkatkan daya saing ekonomi yang lebih besar, fleksibilitas pasar kerja, dan pertumbuhan lapangan pekerjaan. Tidak mengherankan, akibat tekanan tersebut, bidang hukum ketenagakerjaan juga telah kehilangan maknanya. Teori ini dipengaruhi oleh pandangan para pakar konservatif
Chicago tentang hukum dan ekonomi, seperti yang ditunjukkan oleh Harold Demsetz, M ichael Wachter dan Oliver Williamson (Dau-Schmidt, 2009: 5).

Para pakar Teori Ekonomi Kelembagaan Baru, diantaranya adalah Ronald H. Coase dan Douglass C. North. M enurut teori ini, selalu terdapat cara bagi setiap individu untuk berperilaku menyimpang dan oleh karena itu sistem ekonomi tidak dapat diserahkan ke pasar (free market) seperti dalam Teori Ekonomi Neoklasik. Dalam hal ini diperlukan kelembagaan non-pasar (non market institution) untuk tujuan melindungi pasar supaya tidak terjebak dalam kegagalan yang tidak berujung, yaitu melalui cara membuat aturan main atau kelembagaan (Erani Yustika, 2008: xi).

Dalam konteks PHK, para pakar Teori Ekonomi Kelembagaan Baru juga mengusulkan agar masalah PHK diatur dalam peraturan perundang-undangan. Pandangan demikian dikemukakan dengan mengkritik tiga pandangan Epstein tentang PHK, yaitu: pertama, pemberi kerja yang rasional tidak akan memecat pekerja yang produktif; kedua, citra buruk terhadap pemberi kerja jika PHK dilakukan sewenangwenang; dan ketiga, doktrin 'at-will termination' adalah cara yang baik untuk memotivasi pekerja (Davies, 2004: 157).

Kritik pertama, justru terdapat sekurang-kurangnya dua situasi yang menunjukkan rasionalitas bagi pemberi kerja untuk memecat pekerja yang produktif. Pertama, penyelidikan dan pelatihan kerja kepada pekerja yang melanggar tata tertib kerja akan memerlukan biaya segera yang harus disediakan pemberi kerja, sedangkan manfaatnya hanya akan terasa dalam jangka panjang. Kedua, pemberi kerja memecat pekerja yang produktif, namun pemberi kerja mungkin telah menerima skim pembayaran atas 'manfaat yang tertunda'. Contohnya adalah pemberian upah kepada pekerja pada skala upah yang meningkat berdasarkan usia. Tujuan skim ini untuk memberi motivasi kepada para pekerja untuk loyal kepada perusahaan. Dalam contoh situasi ini, pemberi kerja dapat membuat efisiensi biaya jangka pendek dengan memecat pekerja yang melanggar tata tertib perusahaan sebelum pekerja berhak untuk memperoleh upah yang lebih tinggi di bagian skala atas (Note, 1989: 520).

Kritik kedua, mengenai citra buruk terhadap pemberi kerja. Pendapat tersebut akan berfungsi jika semua pihak mempunyai informasi yang lengkap dan benar, namun 
dalam praktiknya pendapat tersebut tidak langsung benar. Calon pekerja mungkin tidak dapat mengetahui informasi yang sangat banyak mengenai rekrutmen pekerja baru oleh pemberi kerja. Bahkan para pekerja yang sedang bekerja pada pemberi kerja mungkin tidak tahu mengenai tindakan pemberi kerja. Pemberi kerja mungkin dapat menyembunyikan alasan PHK yang sebenarnya dengan mengemukakan bahwa PHK yang terjadi adalah atas alasan penurunan permintaan produksi (Note, 1989: 524). Oleh karena itu, hal ini menunjukkan bahwa oportunis pemberi kerja adalah ancaman sebenarnya dan tidak dibenarkan oleh kekuatan pasar. Hal ini menjustifikasi perlunya peraturan perundangundangan untuk mengatur kewenangan pemberi kerja dalam melakukan PHK.

Kritik ketiga, pendapat bahwa doktrin 'at-will termination' adalah cara yang baik untuk memotivasi pekerja tidaklah benar. Jika pekerja merasa tidak aman, pekerja hanya akan melakukan kewajiban-kewajiban minimal yang diperlukan dan bahkan mengambil kesempatan untuk mengabaikan kewajiban. Pekerja akan melakukan pekerjaan yang terbaik jika pemberi kerja memberi kepercayaan yang tinggi. Jika pekerja merasakan bahwa pemberi kerja mempercayainya melakukan kerja yang baik, pekerja akan membayar kepercayaan itu dengan bekerja keras dan melakukan yang terbaik bagi perusahaan. Pemberi kerja dapat menciptakan lingkungan perusahaan yang penuh kepercayaan dengan memberi pekerja kebebasan membuat pertimbangan dan memberi masukan, bukannya langsung menyelidik pekerja, dan dengan menghindari situasi dimana pekerja merasakan selalu berada di bawah ancaman PHK (Davies, 2004: 158). Dari perspektif ini, peraturan perundang-undangan yang mengatur PHK dapat memberi manfaat kepada pemberi kerja dengan meningkatkan loyalitas dan produktivitas pekerja.

\section{KESIM PULAN DAN SARAN}

Para pakar ekonomi mempunyai cara pandang yang berbeda terhadap persoalan PHK jika dikaitkan dengan perlu tidaknya campur tangan peraturan perundang-undangan untuk mengatur PHK. Penganut Teori Ekonomi Neoklasik memandang bahwa pemberi kerja seharusnya tidak diatur dan tidak dibatasi kewenangannya dalam melakukan PHK karena cara tersebut hanya akan menyebabkan perusahaan menjadi tidak efisien dan tidak produktif. Sementara menurut penganut Teori Ekonomi Kelembagaan Baru, justru pengaturan PHK melalui peraturan perundang-undangan akan memberi manfaat kepada perusahaan agar menjadi lebih produktif dan efisien. Sementara itu, ditinjau dari perspektif kepentingan hak asasi manusia, kew enangan pemberi kerja dalam melakukan PHK adalah terbatas. Pemberi kerja tidak boleh melakukan PHK kepada pekerja tanpa alasan yang adil dan rasional. Pekerja tidak boleh diperlakukan seperti modal atau komoditas lainnya yang dengan mudah dapat dimanfaatkan atau dibuang. Untuk melindungi hak tersebut, maka diperlukan adanya campur tangan peraturan perundang-undangan yang mencerminkan keadilan, baik substantif maupun prosedural.

\section{DAFTAR PUSTAKA}

Allen, Robbin, et.al., 2007, Employment Law and H uman Rights, edisi-2, England, O xford U niversity Press.

Betten, Lammy, 1995, "The Role of the Contract in Transforming Labour relations" in Betten, Lammy, et.al. (ed), The Employment Contract in Transforming Labour Relations, The Hague, Kluwer Law International.

Collins, Hugh, 1991, "The Meaning of Job Security", Industrial Law Journal, Vol. 20, No. 4.

Dau-Schmidt, Kenneth G., et.al., 2009, Labor and Employment Law and Economics, Cheltenham, Edward Elgar publishing.

Davies, A nne C.L., 2004, Perspectives on Labour Law, Cambridge, Cambridge U niversity Press.

Epstein, R.A., 1984, "In defense of the contract at will", U niversity of Chicago Law Review, Vol. 51.

Hepple, Bob, 1981, "A right to Work?", Industrial Law Journal, Vol. 10, No. 1.

Hepple, Bob, 1986, The M aking of Labour Law in Europe: A C omparitive Study of $\mathrm{N}$ ine C ountries up to 1945, London and New York, Mansell Publishing Limited.

Krueger, Alan B., 1991, "The Evolution of U njust-D ismissal Legislation in The U nited States", Industrial and Labor Relations Review, Vol. 44, No. 4.

D rzewicki, Krzysztof, 2001, "The Right to Work and Rights in Work" in Asbjorn et.al. (ed), Economic, 
Social and Cutural Rights, The Hague, Kluwer Law International.

Miceli, Thomas, 2004, The Economic Approach to Law, Edisi-2, Stanford, Stanford U niversity Press.

Note, 1989, "Employer O pportunism and the Need for a Just C ause Standard", H arvard L aw Review, Vol. 103, No. 2.

Posner, Richard, 1984, "Some Economics of Labor Law", The U niversity of Chicago Law Review, Vol. 51, No. 4.

Rao, EM, 2007, Industrial Jurisprudence, New Delhi, LexisN exis Butterworths.

Santoso, Budi dan D heviana, Ratih, 2012, "Eksistensi Asas Kebebasan Berkontrak dalam Perjanjian Kerja", A rena H ukum, Vol. 6, No. 3.

Steni, Bernadinus, 2008, M embuat HAM Bermakna, Jakarta, HU MA.

Yustika, Ahmad Erani, 2008, Ekonomi Kelembagaan: Definisi, Teori, dan Strategi, Malang, Bayumedia Publishing.

Charter of Fundamental Rights of the European Union, http:/ / eur-lex.europa.eu/ LexU riServ/ LexU riServ.do?uri=0 J:C :2010:083:0389:0403:EN:PDF, diunduh pada Rabu, 18 N ovember 2015, jam 22.40 WIB.

C ollins, Hugh, "Theories of Rights as Justifications for Labour Law", http:// www.Ise.ac.uk/ collections/ law/ staff\% 20publications\% 20full\%20text/ collins/ ch9.pdf, diunduh pada Sabtu, 14 N ovember 2015, jam 21.35 WIB.

Convention on the Elimination of All Forms of Discrimination A gainst Woman, http:/ / www.un.org/ womenwatch/ daw/ cedaw/ text/ econvention.htm, diunduh pada Jumat, 20 November 2015, jam 21.35 WIB.

Evju, Stein, "Labour is not a Commodity: A Reappraisal", http:// www.Labour lawresearch.net/ Portals/ 0/ 06\% 20Labour \% 20-\% 20C ommodity\% 20Reppraisal.pdf, diunduh pada Rabu, 18 November 2015, jam 22.10 WIB.

Investovedia, "Definition of Labor Theory Of Value", http:// www.investopedia.com/ terms/l/labortheory-of-val ue.asp \#axzz2D N s1SjMA, diunduh pada Rabu, 70 ktober 2015, jam 22.15 WIB.

Kaufman, Bruce E., "Economic A nalysis of Labor Mar- kets and Labor Law: An Institutional/Industrial Relations Perspective", http:/ / www.employmentpolicy.org/ topic/ 578/ research/ economic-analysislabor-markets-and-labor-law-institutional industrialrelations-p, diunduh pada Senin, 260 ktober 2015, jam 22.17 W IB.

Konstitusi ILO, http:/ / www.ilo.org/ ilolex/ english/ iloconst.htm, diunduh pada Senin, 7 Desember 2015, jam 20.45 WIB.

Konvensi Pemutusan Hubungan Kerja 1982, http:// www.ilo.org/ wcmsp5/groups/ public/ -asia/ -robangkok/ -ilo-jakarta/ documents/ legaldocument/ wcms_149912.pdf, diunduh pada Rabu, 18 N ovember 2015, jam 23.05 WIB).

M antouvalou, Virginia, "A re Labour Rights Human Rights?", http:// www.ucl.ac.uk/ laws/ Iri/ papers/ VM antouvalou_Are_labour_rights_human_rights.pdf, diunduh pada Rabu, 4 N ovember 2015, jam 23.20 WIB.

The European Social Charter 1961, http:// polis.osce.org/library/f/ 2667/ 466/ C oE-ITA -R PT2667-EN-46, diunduh pada Rabu, 18 November 2015, jam 20.30 WIB.

The European Social Charter 1996, http:// www.coe.int/ t/ dG H I/ monitoring/ Social charter/ Presentation / ESCRBooklet/ English.pdf, diunduh pada M inggu, 15 November 2015, jam 21.50 W IB. 